\title{
Barriers Facing E-Service Technology in Developing Countries: A Structured Literature Review with Nigeria as a Case Study
}

\author{
Kazeem Oluwakemi Oseni \\ School of Computing \\ University of Portsmouth \\ Portsmouth, United Kingdom \\ Kazeem.oseni@port.ac.uk
}

\author{
Dr. Kate Dingley \\ School of Computing \\ University of Portsmouth \\ Portsmouth, United Kingdom \\ Kate.dingley@port.ac.uk
}

\author{
Dr. Penny Hart \\ School of Computing \\ University of Portsmouth \\ Portsmouth, United Kingdom \\ Penny.hart@port.ac.uk
}

Abstract - E-Government services adoption rate is rapidly increasingly in the developing and lower-middleincome countries for promoting good governance capability and accountability of public organisations. E-Government services are helping to boost government revenue, very fast and secured transactions, reduce corruption through the use of modern technology and transparent operations. It is imperative to state that the e-Service in an e-Governance domain has been gaining more attention over past two decades. This paper will examine a structured literature review (SLR) of the barriers facing E-Service Technology in developing countries with Nigeria as a case study. In this study, the use of a structured literature review gives rise to reviewing papers from conferences on Google Scholar between 2009 and 2014. A total of 3100 papers were reviewed using content analysis and 68 papers from Google Scholar after careful filtering, classification and analysis met the inclusion criteria for barriers facing E-Service adoption and implementation including the success factors. A model has emerged that captures both the barriers facing E-Service technology and solutions, it has been identified that the public is much aware of E-Services, but the successful adoption and implementation remains a misery due to various barriers.

Keywords - E-Government; E-Service; Technology; Developing Countries; Nigeria.

\section{INTRODUCTION}

E-Government as an identified activity was unknown before now but because of rapid growth, there is a likely future direction for the research domain (Heeks and Bailur, 2007). The implementation of information and communication technology (ICT) in most developed countries across all sectors of the economy have generally reached a maturity stage (Nakkas et. al., 2015) compared to developing countries where E-Government services and activities are still very low (Mundy and Musa, 2010).

The successful deployment of E-Service technology will no doubt help to boost government revenue, very fast and secured transactions, reduce corruption through the use of modern technology and transparent operations (Haque and Pathrannarakul, 2013).

Danish (2006) suggested that E-Government services could increase the rate of development in a country and even enhance democracy. He is of the opinion that this could, however, be successfully implemented despite various barriers (Danish, 2006).

Sponsors - Faculty of Technology and School of Computing, University of Portsmouth, United Kingdom.
Though, implementing successful E-Service technology in this part of the world will not come without barriers considering the unstable and fragile economies in most developing countries. World bank (2014) defined developing countries as low and middle-income countries and Nigeria was selected as an illustrative case of a developing country with middle income generating power and endowed with natural resources but is yet to benefit from the economic and potential values of E-Service technology usage which will contribute immensely to business and economic advancement as witnessed in developed countries (Hasan, 2015).

This paper will examine a structured literature review of the barriers facing E-Service Technology in developing countries with Nigeria as a case study. This study is important for E-Government researchers as it will serve as a reference point in conducting further thorough research in barriers facing E-Service technology, the way forward and how successful implementation could be achieved. This study has a well-laid structure; they are Introduction, Literature Review, Research Method, Finding and Analysis, Conclusion and Recommendations, References.

\section{LITERATURE REVIEW}

\section{A. E-Government Concept}

The concept of E-Government emerged in the late 1990s despite that the history of computing as a tool in government establishments could be traced back to the origin of computer itself and just like other eplatform concepts such as e-commerce, the term egovernment was born out of internet world (Ake and Horan, 2004). Few decades ago, e-Government as a term and as an identified activity was unknown before now and because of rapid growth, there is a possible future direction for the research domain (Heeks and Bailur, 2007).

\section{B. E-Service Concept}

Electronic Service shortened as 'e-Service' which refers to any service that is provided by any electronic means. For example, services provided through Internet/website, mobile devices or kiosk (Bhuiyan, 2011).

The term e-Service represents content centered and interactive internet-based customer service "driven by the customer and integrated with related organisational customer support processes and technologies with the goal of strengthening the customer-provider relationship” Ruyter et. al (2001). 


\section{Types of E-Service}

There are many E-Services available today at all levels both in private and government establishments in most developed and developing countries. According to Khadaroo et. al. (2013), the following are various types of E-Services:

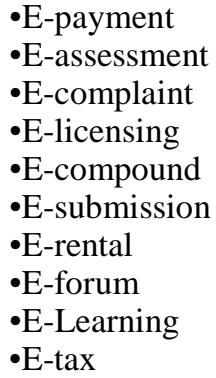

\section{E-Service}

Adoption and

Implementation in Nigeria

The emergence of democratic rule in Nigeria in 1999 started the E-Government journey in the country with the establishment of the National Information Technology Development Agency (NITDA) under the Federal Ministry of Science and Technology which focus on the creation of framework to coordinate and regulate the information technology activities in the country (Nkem and Amanze, 2011).

\begin{tabular}{|l|l|l|}
\hline \multicolumn{3}{|l|}{ E-Government Ranking - Africa Top 20 Countries } \\
\hline \multicolumn{4}{|l|}{} \\
\hline & Country & Level of Income \\
\hline 1 & Tunisia & Upper Middle \\
\hline 2 & Mauritius & Upper Middle \\
\hline 3 & Egypt & Lower Middle \\
\hline 4 & Seychelles & Upper Middle \\
\hline 5 & Morocco & Lower Middle \\
\hline 6 & South Africa & Upper Middle \\
\hline 7 & Botswana & Upper Middle \\
\hline 8 & Namibia & Upper Middle \\
\hline 9 & Kenya & Low \\
\hline 10 & Libya & Upper Middle \\
\hline 11 & Ghana & Lower Middle \\
\hline 12 & Rwanda & Low \\
\hline 13 & Zimbabwe & Low \\
\hline 14 & Cape Verde & Lower Middle \\
\hline 15 & Gabon & Upper Middle \\
\hline 16 & Algeria & Upper Middle \\
\hline 17 & Swaziland & Lower Middle \\
\hline 18 & Angola & Upper Middle \\
\hline 19 & Nigeria & Lower Middle \\
\hline 20 & Cameroon & Lower Middle \\
\hline & & Source: United Nations, 2014. \\
\hline & & \\
\hline &
\end{tabular}

Table 1 - Africa E-Government Ranking 2014.
The E-Government initiative was established with the aim of providing a level of interaction between citizens and government via business transactions, retrieval of information, advertisement and submission of tenders (Nkem and Amanze, 2011). Despite the fact that most government agencies and private companies have online presence today through creation of websites, the results of research by many researchers into various E-Government activities in developing countries including Nigeria shows most websites have low capacity to accommodate full citizens online interaction. E-Government services and activities are still adjudged to be very low (Mundy and Musa, 2010; Nkem and Amanze, 2011).

The security issues associated with E-payments in the country have made the adoption of E-Service to be very low while the high level of corruption in the country have contributed the low implementation of E-Government projects in Nigeria (Ayoola, 2013).

The E-Government ranking in Nigeria is still very low (Mundy and Musa, 2010) despite the fact that Nigeria is currently the largest economy in Africa which represent an economy of about $\$ 509 \mathrm{bn}$. As shown in Tab. 1 above, Nigeria currently occupying $19^{\text {th }}$ position in the Africa E-Government ranking as released by United Nations in 2014. The low EGovernment in the country is associated with various barriers as mentioned in findings and analysis section.

\section{RESEARCH METHOD}

\section{A. Literature Selection}

Researchers adopted the method of investigating relevant conference papers from Google Scholar as indicated in Fig. 1 below as there is a need to use a robust search method which led to the use of systematic literature review as suggested by Watson and Webster (2002). There are many conference materials, journals, books, online papers on egovernment services. Therefore, it is a herculean task to read all the references.

The literature review search focussed on the abstracts and keywords as there are many papers on egovernment services, this will allow a view of main themes in e-service research. The researchers made use of google scholar because its credibility and simple way conducting a broad search for material. It is interdisciplinary allowing the researcher to find the relevant references in journals that are not obviously connected to e-government or its allied topics. In addition, one could use google scholar from one place to search across many disciplines and sources such as articles, books, online repositories and universities websites. Google scholar helps in finding relevant works by researchers across the world.

The literature review analysis and techniques used for the process, synthesis and participation of the evidence were similar to the ones used in the research conducted by (Watson and Webster, 2002; Yusuf et. al. 2014; Nikkas et. al, 2015). 


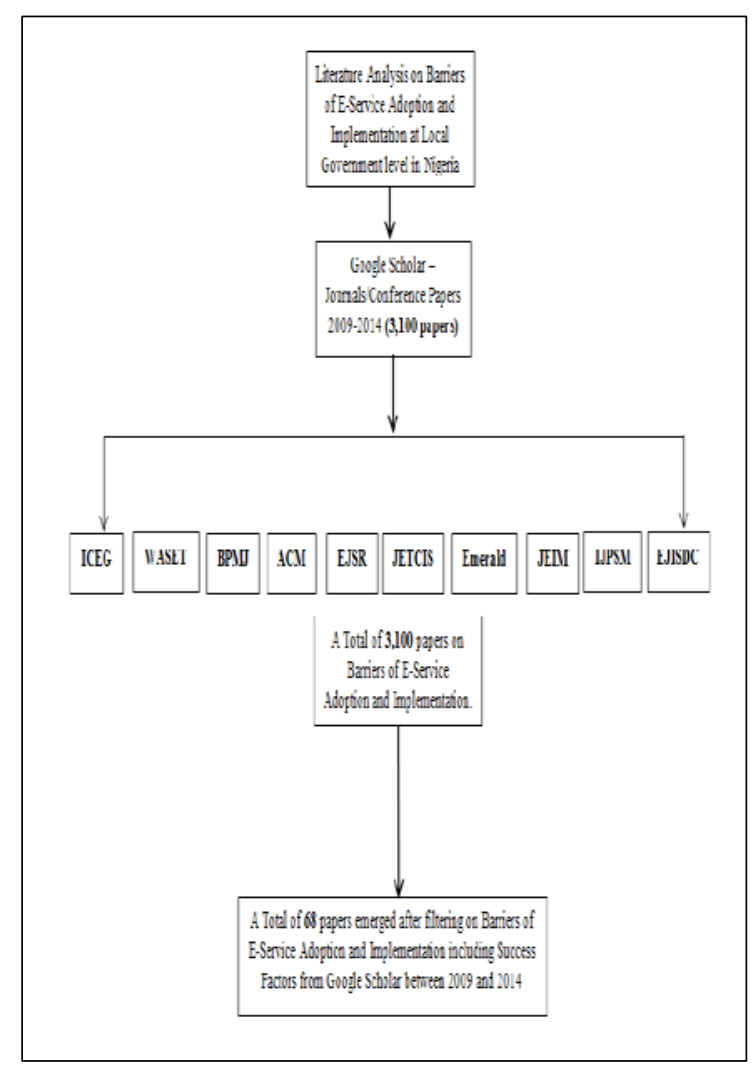

Figure 1 - Literature Review Analysis.

$\checkmark$ ICEG - International Conference on eGovernment

$\checkmark$ WASET - World Academy of Science, Engineering and Technology

$\checkmark$ BPMJ - Business Process Management Journal

$\checkmark$ ACM - Association of Computer Machinery

$\checkmark$ EJSR - European Journal of Scientific Research

$\checkmark$ JETCIS - Journal of Emerging Trends in Computing and Information Sciences

$\checkmark \quad$ Emerald Group publishing papers

$\checkmark$ JEIM - Journal of Enterprise Information Management

$\checkmark$ IJPSM - International Journal of Public Sector Management

$\checkmark$ EJISDC - Electronic Journal on Information Systems in Developing Countries.

\section{B. Data Sources and Search technique}

Detailed and comprehensive searches were performed on the on-line databases as indicated in Fig. 1 above. Using a structured literature review gives rise to reviewing many papers from Google Scholar between 2009 and 2014. Many keywords were also identified and the researchers carefully did a thorough analysis on these, plot graphs to produce themes, trends and research keywords, full details in finding and analysis section. A total of 3100 papers were reviewed using content analysis and 68 papers after careful filtering, classification and analysis met the inclusion criteria for barriers facing E-Service adoption and implementation including the success factors.

\section{FINDINGS AND ANALYSIS}

In this section, the researchers of this paper present findings and analysis based on the content literature analysis. The early research findings were based on reviewing related research works on barriers facing E-Government services development in developing countries especially Nigeria (Gilbert and Balestrini, 2004; Danish, 2006; Mundy and Musa, 2010; Oseni and Dingley, 2014).

The structure of the literature review is shown in Fig. 1 above. A total of 3100 papers were reviewed using content analysis and 68 Papers from Google Scholar between 2009 and 2014 after careful filtering, classification and analysis met the inclusion criteria for barriers facing E-Service adoption and implementation including the success factors.

\section{A. RESULTS ON THE BARRIERS FACING E-SERVICE TECHNOLOGY IN DEVELOPING COUNTRIES}

There is no doubt that using or adopting a new system and technology might come with some challenges (Goran and Erik, 2014). The fact that a technology which has been effectively adopted by a particular country or culture does not necessarily means it will work the same way in another culture, even though they may look similar. In reviewing previous studies and from the result of the pilot study conducted by Oseni and Dingley (2014) between 23rd September and 30th October 2014, the following barriers were identified as shown in Fig. 2 below;

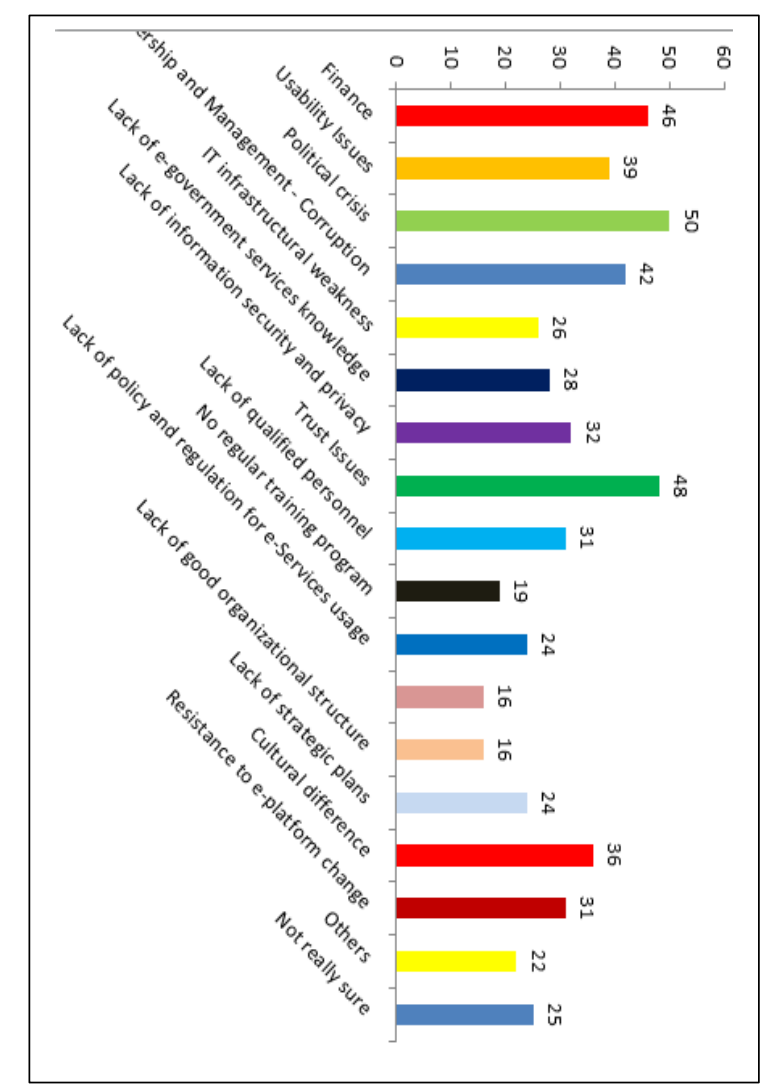

Figure 2 - Barriers facing E-Service Technology in Developing Countries. 
There are various barriers facing E-Service Technology in Developing Countries as obtained and analysed by the survey results, higher scores are Political crisis, Trust issue, Finance, Usability Issues, Leadership and Management - Corruption, Cultural difference, Lack of information security and privacy, Resistance to E-Platform change, Lack of EGovernment service knowledge and others as indicated in Fig. 2 above.

\section{B. RESULTS FROM GOOGLE SCHOLAR CONFERENCE PAPERS (2009-2014)}

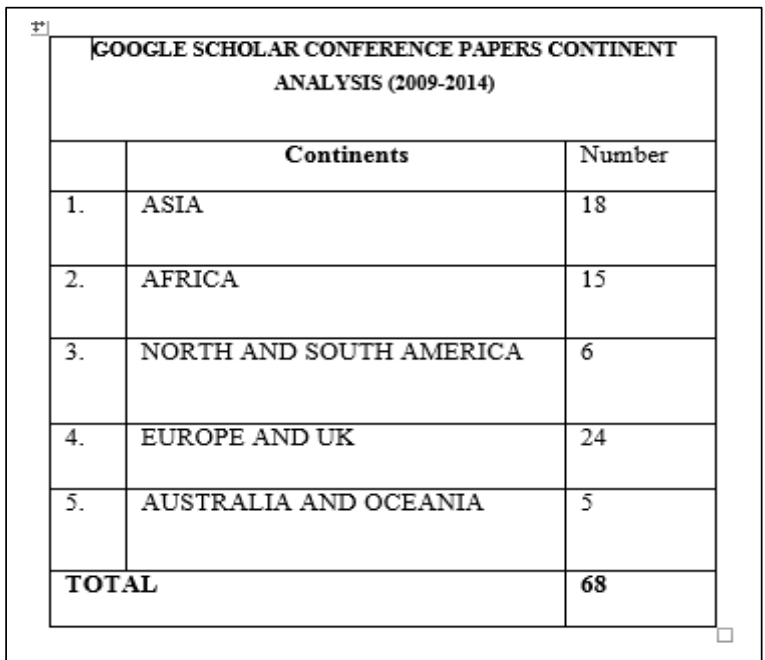

Table 2 - Google Scholar Continents Analysis 2009-2014.

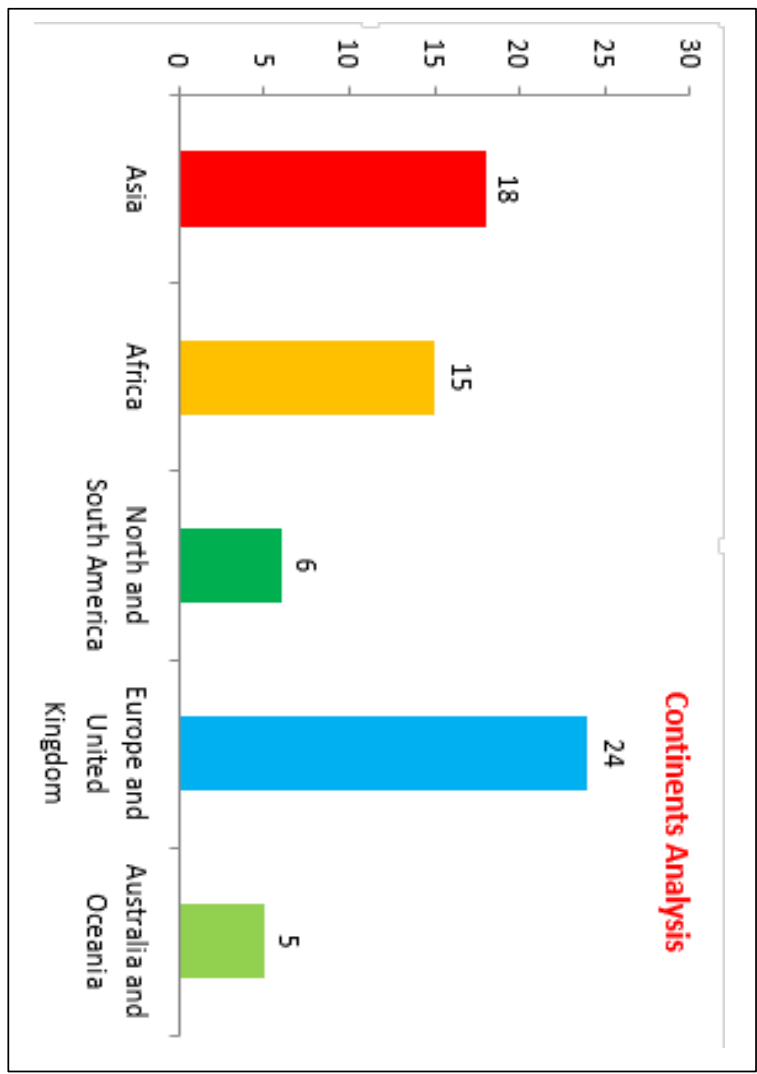

Figure 3 - Google Scholar Continents Graphical Analysis 2009-2014.
1. Continent Analysis: From Tab. 2 and Fig. 3 above, the results shows Europe and UK have the highest number of journals from the Google Scholar literature review between 2009 and 2014 with 24 journals representing 35\% of the total. This is closely followed by Asia with 18 journals representing 26\%. Others are North and South America 6 Journals (9\%), Australia and Oceania 5 Journals (8\%), Africa 15 Journals which represent $22 \%$.

\begin{tabular}{|l|c|l|}
\hline \multicolumn{3}{|c|}{$\begin{array}{r}\text { GOOGLE SCHOLAR CONFERENCE PAPERS YEARLY } \\
\text { ANAL YSTS (2009-2014) }\end{array}$} \\
\hline & Year & Number \\
\hline 1 & 2009 & 8 \\
\hline 2 & 2010 & 6 \\
\hline 3 & 2011 & 12 \\
\hline 4 & 2012 & 30 \\
\hline 5 & 2013 & 5 \\
\hline 6 & 2014 & 7 \\
\hline TOTAL & 68 \\
\hline
\end{tabular}

Table 3 - Google Scholar Year Analysis 2009- 2014.

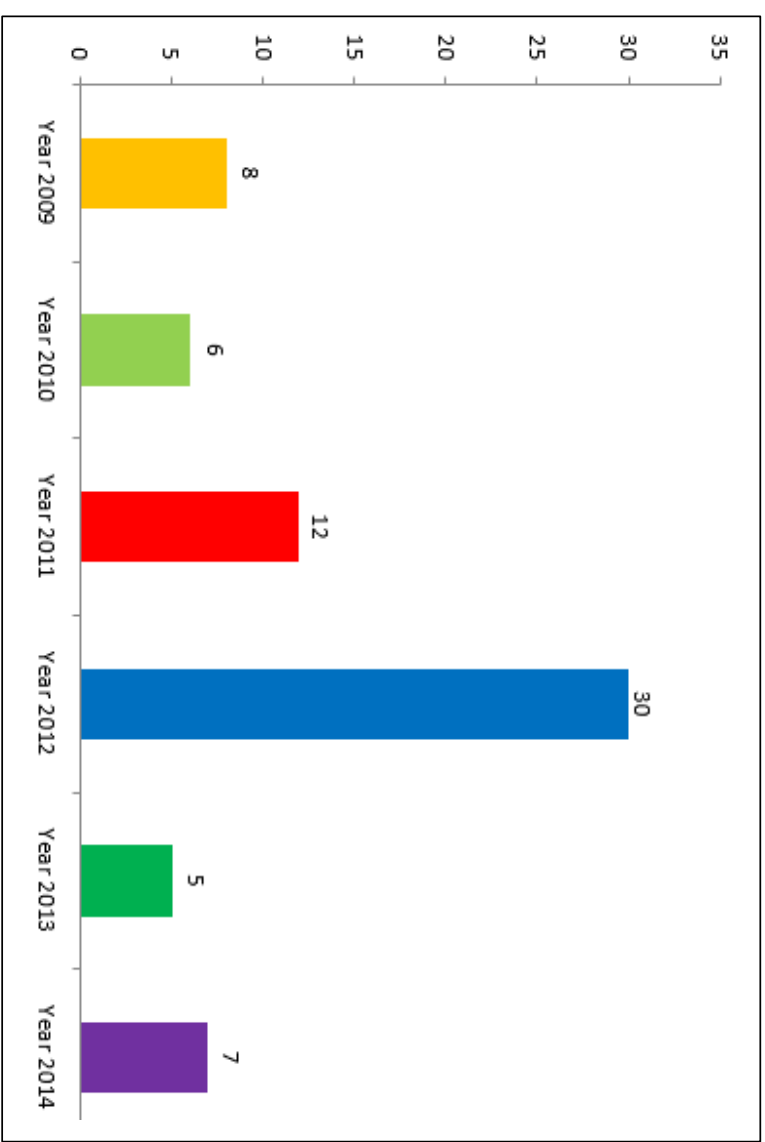

Figure 4 - Google Scholar Year Graphical Analysis 20092014. 
2. Year Analysis: The analysis available from Tab. 3 and Fig. 4 respectively shows the Google Scholar literature review between 2009 and 2014 indicated that Year 2012 has 30 journals which are the highest representing $44 \%$ of the total while Year 2013 has the lowest number of journal with 5 journals representing 7\%. The year 2011 with 12 journals (18\%), 2009 has 8 (18\%), the year 2014 has 7 representing (10\%) while 2010 has 6 representing (9\%).

The research in this field before the year 2012 was very low, but the year 2012 shows a significant improvement in a number of researches carried out. The declined in the study were also witnessed in the following years of 2013 and 2014.

\begin{tabular}{|c|c|c|}
\hline \multicolumn{3}{|c|}{$\begin{array}{l}\text { GOOGLE SCHOLAR CONFERENCE PAPERS } \\
\text { RESEARCH METHODS/AETHODOLOGIES (2009-2014) }\end{array}$} \\
\hline & $\begin{array}{c}\text { RESEARCH } \\
\text { METHODS/METHODOLOGIES }\end{array}$ & Number \\
\hline 1 & Case study & 8 \\
\hline 2 & Comparative analysis & 1 \\
\hline 3 & Content Analysis & 1 \\
\hline 4 & Descriptive approach & 1 \\
\hline 5 & Exploratory study & 2 \\
\hline 6 & Framework & 8 \\
\hline 7 & Interview & 1 \\
\hline 8 & Investigation method & 1 \\
\hline 9 & Literature Review & 11 \\
\hline 11 & Model & 18 \\
\hline 12 & $\begin{array}{l}\text { Participatory } \quad \text { Stakeholder } \\
\text { Assessment }\end{array}$ & 1 \\
\hline 13 & Qualitative Analysis & 2 \\
\hline 14 & Quantitative Empirical Studies & 1 \\
\hline 15 & Questionnaire & 1 \\
\hline 16 & Semi-structured interviews & 1 \\
\hline 17 & Survey & 9 \\
\hline 18 & Systematic Review & 1 \\
\hline T0 & $\overline{\mathrm{AL}}$ & 68 \\
\hline
\end{tabular}

Table 4 - Google Scholar Research Methods/Methodologies Analysis (2009 - 2014)

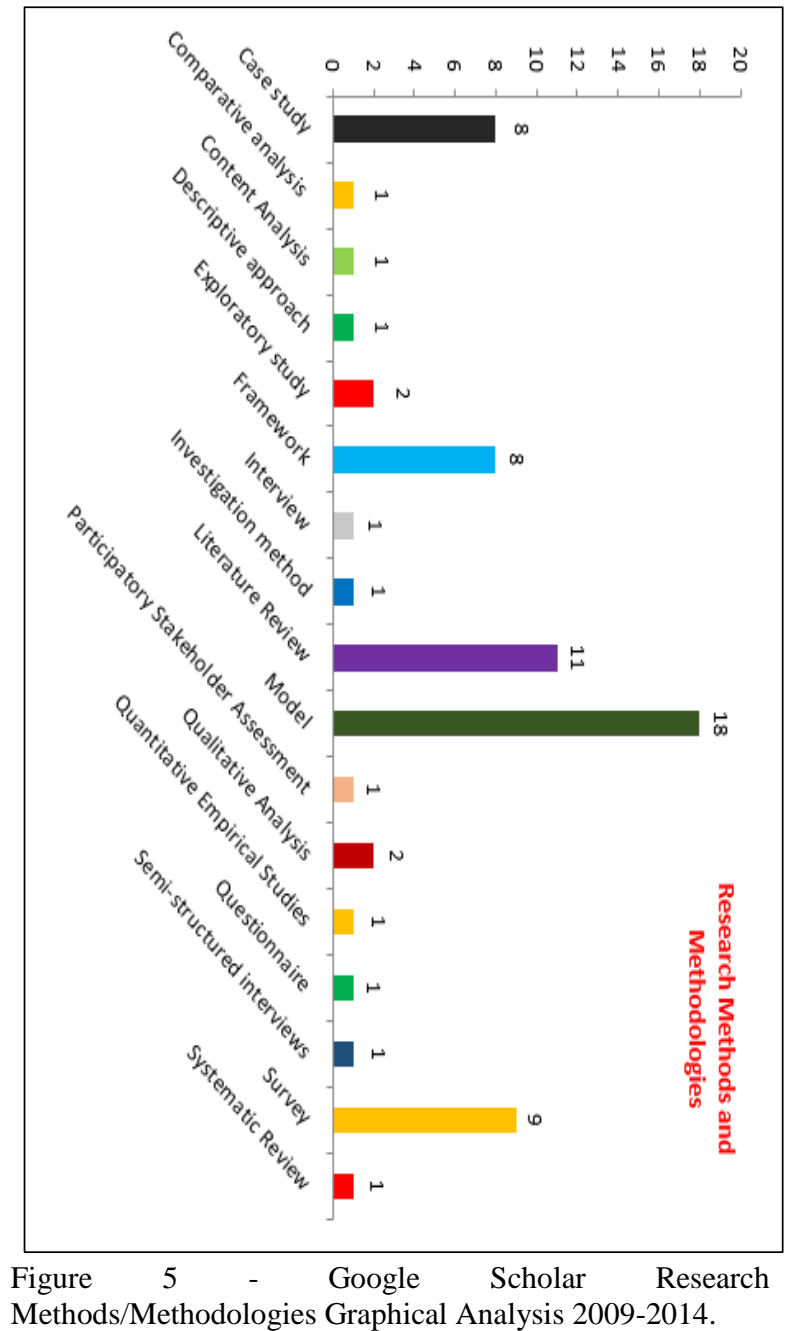

3. Research Methods/Methodologies Analysis: As shown in Tab. 4 and Fig. 5 above, there are various research Methods/Methodologies used in the study through Google Scholar. The most common methodologies used are Model with 18 journals representing (27\%), Literature Review 11 (16\%), Survey 9 (13\%), Case study 8 (18\%) and Framework 8 (18\%).

\section{STATISTICAL ANALYSIS OF THE SOLUTION TO THE BARRIERS FACING E-SERVICE TECHNOLOGY IN DEVELOPING COUNTRIES}

Following the pilot study conducted by Oseni and Dingley (2014) to determine the barriers facing EService technology in developing countries as analysed in fig. 2 above, a follow-up interview was done recently by the researchers to determine the solutions to earlier identified barriers. 30 senior officers at Surulere Local Government, Lagos in Nigeria were interviewed recently and the results presented below using SPSS software where chisquare, correlation and T-test results were obtained. 


\begin{tabular}{|l|r|r|r|}
\hline & Value & \multicolumn{1}{|c|}{ df } & \multicolumn{2}{|c|}{$\begin{array}{c}\text { Asymp. Sig. (2- } \\
\text { sided) }\end{array}$} \\
\hline $\begin{array}{l}\text { Pearson Chi- } \\
\text { Square }\end{array}$ & $7.242^{\mathrm{a}}$ & 7 & .404 \\
$\begin{array}{l}\text { Likelihood Ratio } \\
\text { Linear-by-Linear }\end{array}$ & 9.209 & 7 & .238 \\
$\begin{array}{l}\text { Association } \\
\text { N of Valid Cases }\end{array}$ & 30 & 1 & .144 \\
\hline
\end{tabular}

a. 16 cells (100.0\%) have expected count less than the minimum expected count is .47 .

Table 5 - Chi-Square Test on the barriers facing EService Technology

\begin{tabular}{|l|r|r|r|r|}
\hline & & & \multicolumn{1}{c|}{$\begin{array}{c}\text { Std. } \\
\text { Deviation }\end{array}$} & $\begin{array}{c}\text { Std. } \\
\text { Error } \\
\text { Mean }\end{array}$ \\
\hline $\begin{array}{l}\text { Main barriers } \\
\text { facing E-Service } \\
\text { Technology }\end{array}$ & 30 & 4.33 & 2.454 & .448 \\
\hline
\end{tabular}

Table 6 - One-Sample Statistics T-Test on the barriers facing E-Service Technology

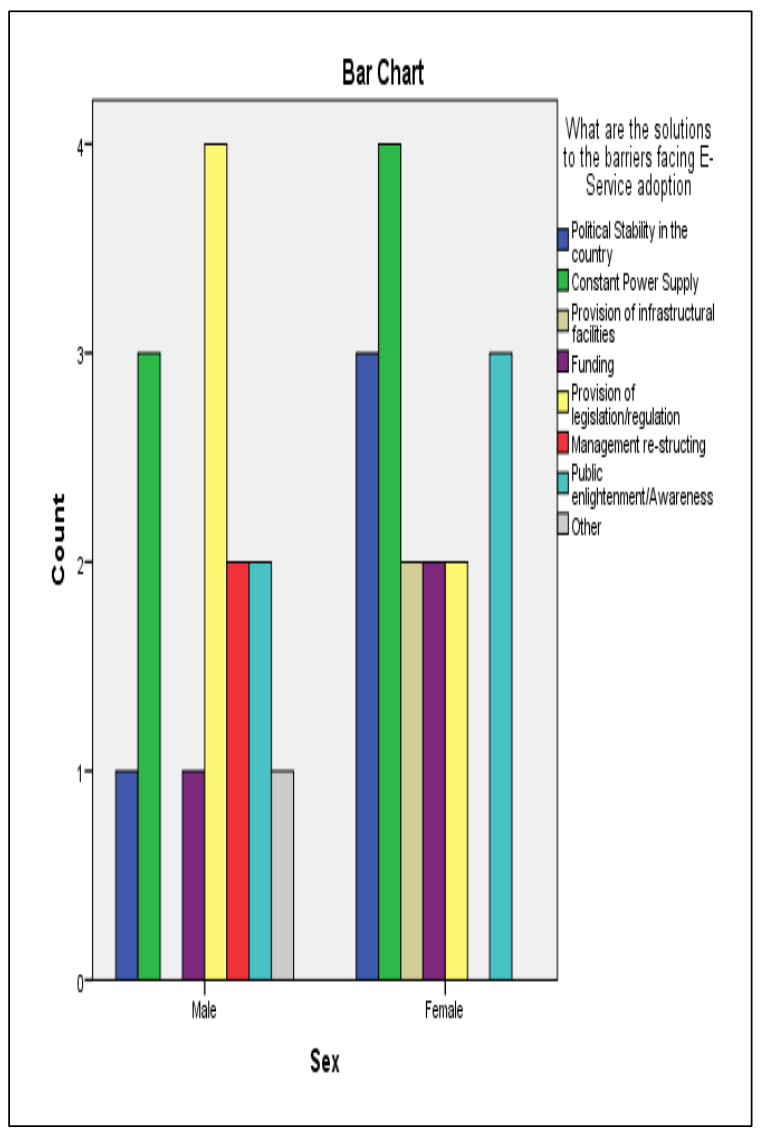

Figure 6 - Bar Chat on the solutions to the barriers facing E-Service Technology

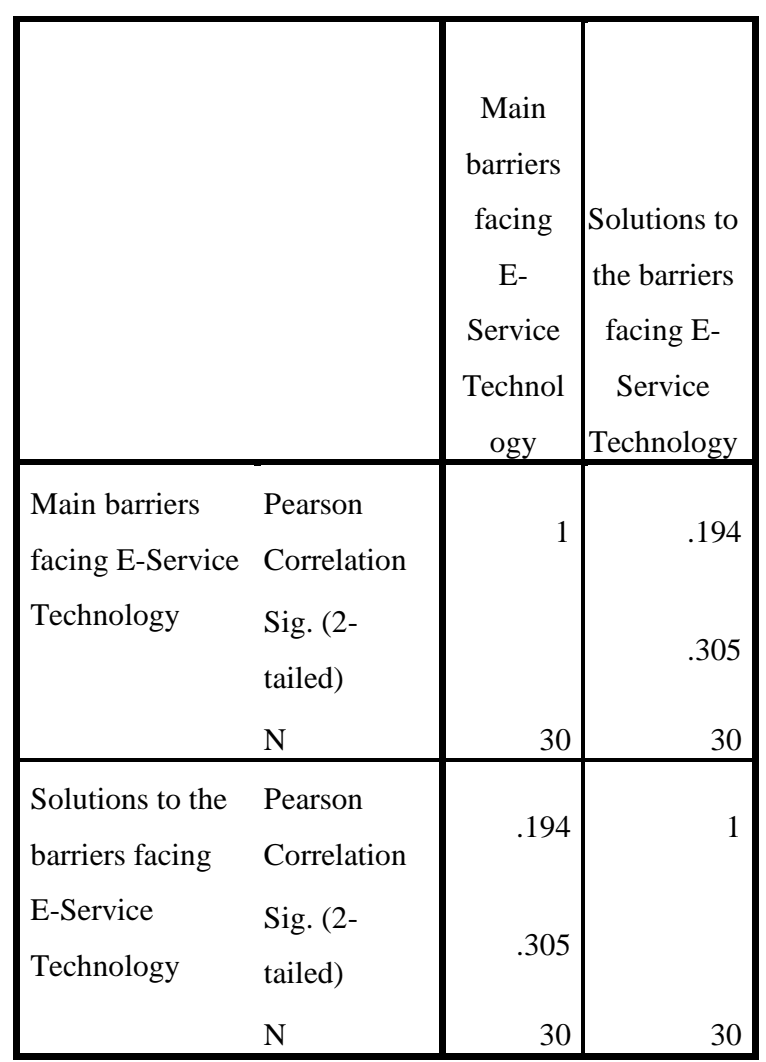

Table 7 - Correlation results for the barriers and solutions to the barriers facing E-Service Technology in Developing Countries

From the above analysis, the use of chi-square is very important in this study as categorical variables are involved from a single population. This will determine if there is a significant association between the variables as demonstrated in Tab. 5 on the barriers facing e-service technology. A good example is classification of gender in the survey conducted, there is a need to classify the participants in their gender either male or female and chi-square will determine whether gender is related to the pattern of the barriers chosen facing the e-service technology in developing countries.

T-test statistical analysis, on the other hand, is useful when we need to compare performance in two conditions. T-test will help to decide if the difference between the conditions is real or merely fluctuations from one-time testing to another. In Tab.6, one sample T-test allows us to test whether a sample mean differs significantly from hypothesized value.

The researchers also analysed the results using correlation test in order to find a linear relationship between barriers facing e-service technology in developing countries and solutions. The relationship could either be positive or negative and it is significant at the 0.05 level (2-tailed) as indicated in Tab. 7 above. The specified correlation tests values will always be given in the correlation section. The null hypothesis is often rejected if $\mathrm{p}<.05$ and since this is a 2-tailed test, the p-value consists of a $0 \%$ chance that the sample correlation is either larger or smaller than .194 and -.194. 


\section{MODEL FOR E-SERVICE TECHNOLOGY IN DEVELOPING COUNTRIES CAPTURING BARRIERS AND SOLUTIONS}

In other to justify the research argument and based on the results obtained from the survey on the barriers facing e-service technology in developing countries and the solutions to the barriers earlier identified which were obtained during the recently conducted interviews with stakeholders in e-service provision at a local government in Nigeria, a model has emerged as shown in Fig. 7 and this captures various factors and solutions to be considered in effective and user friendly e-service technology provision in developing countries.

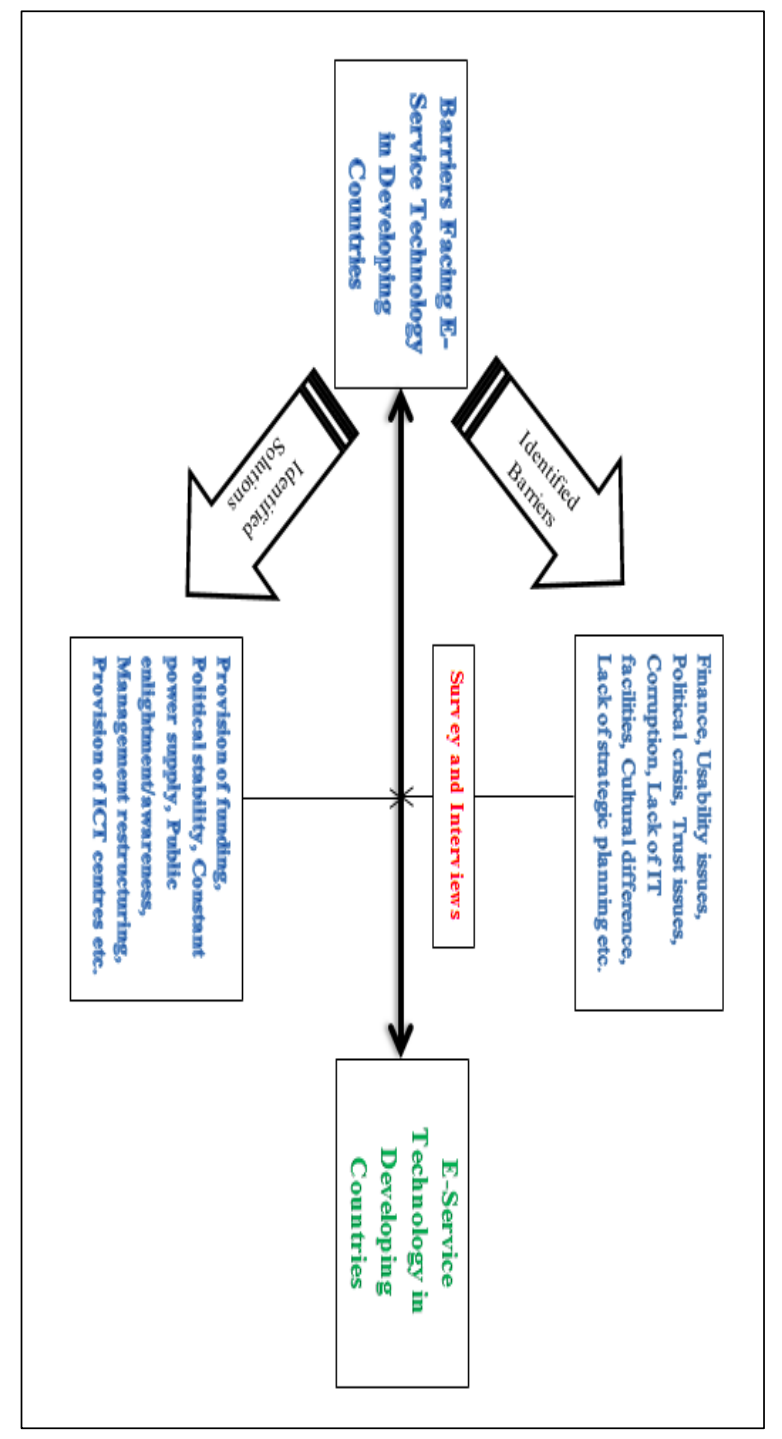

Figure 7 - Proposed E-Service Technology Model

\section{CONCLUSIONS}

We have been able to examine a structured literature review of the barriers facing E-Service Technology in developing countries with Nigeria as a case study. The structured review of the literature showed that there are numerous barriers that could affect E-Service Technology in developing countries.
It also shows in the literature review analysis that the research in E-Service Technology is still very low in developing countries. A model as emerged and this captures various factors to be considered in effective e-service technology provision in developing countries. The use of the model is more prominent in the research methods/methodologies in various literatures reviewed in the Google Scholar conference papers between 2009 and 2014.

Though, e-Governance is still young in many developing countries such as Nigeria, successful EService implementation and adoption will provide increased revenue and the boost economy. More research is now needed to identify and implement cost-effective, usable E-Service Technology systems for the country, and there is a need for government to make positive change in the way services are being delivered to citizen and others stakeholders. Changes should be made to legislation and laws in order to provide an enabling platform for E-Service Technology to flourish in the country. Issues like awareness and availability of services and trust all need further development in order to allow eGovernment services to be delivered and used by citizens.

\section{REFERENCE}

[1] Ake Gronlund and T.A Horan (2004) "Introducing Egovernment: History, Definitions and Issues, Communications of the Association for Information Systems, Volume 15, Page 713-729.

[2] Ayoola T. J (2013) The effect of Cashless Policy of Government on Corruption in Nigeria, The International Review of Management and Business Research, Vol 2, Issue 3.

[3] Bhuiyan, M.S.H (2011) "Public Sector eService Development in Bangladesh: Status, Prospects and Challenges” Electronic Journal of e-Government Volume 9 Issue 1, (pp15 - 29).

[4] Danish Dada (2006) "The failure of e-Government in Developing Countries: A Literature Review" The Electronic Journal on Information Systems in Developing Countries, Volume 26, Issue 1. Page 1-10.

[5] Gilbert D. and Balestrini P. (2004) Barriers and benefits in the adoption of e-government, The International Journal of Public Sector Management, Volume 17, No. 4, page 286-301.

[6] Goran Goldkuhl and Erik Perjons (2014) Focus, Goal and Roles in E-Service Design. Five Ideal Types of the Design Process, E-Service Journal, Volume 9, Issue 2, Page 24-45.

[7] Hasan, M. Mahmudul (2015) E-Government Service Research Development: A Literature Review, International Journal of E-Services and Mobile Applications, 7(1), 22-49.

[8] Haque, S., and Pathrannarakul, P. (2013) The Role of Technology in Enhancing Transparency and Accountability in Public Sector Organizations of Pakistan. International Journal of Economics Business and Management Studies, 2(1), 20-24.

[9] Heeks Richard, and Savita Bailur (2007) "Analyzing egovernment research: Perspectives, philosophies, theories, methods, and practice." Government information quarterly 24.2, pp 243-265.

[10] Khadaroo, I., Wong, M. S., \& Abdullah, A. (2013) Barriers in local e-government partnership: evidence from Malaysia. An International Journal of Electronic Government, 10(1), 19-33. 
[11] Mundy, D and Musa, B (2010) "Towards a Framework for eGovernment Development in Nigeria" Electronic Journal of eGovernment, Volume 8, Issue 2, PP148-161.

[12] Nakkas, Haythem A; Philip J. Scott and Jim S. Briggs (2015) Health Information Technology in Developing Countries: A Structured Literature Review with Reference to the Case of Libya. International Journal of Medical, Health, Pharmaceutical and Biomedical Engineering Vol: 9 No: 1.

[13] Nkem Ekene Osuigwe and Amanze Unagha (2011) Public Libraries and E-Government in Nigeria, The Information Manager Vol. 11 (1\&2).

[14] Oseni, K. and Dingley, K. (2014). 'Challenges of e-Service Adoption and Implementation in Nigeria: Lessons from Asia'. International Science Index 96, International Journal of Social, Education, Economics and Management Engineering, 8(12), 3733 - 3740

[15] Ruyter Ko De, Martin Wetzels and Mirella Kleijnen (2001) "Customer adoption of e-service: an experimental study" International Journal of Service Management, Volume 12, No. 2, pages 184-207.

[16] Schwester, R. (2009) Examining the barriers to e-Government Adoption. Electronic Journal of e-Government, Vol 7(1).

[17] Watson, R. and Webster, J. (2002). 'Analysing the Past to Prepare for the Future; Writing A Literature Review’. MIS Quarterly, 26(2).

[18] Webster, J. and Watson, R.T (2002) Analyzing the past to prepare for the future: Writing a literature review. MIS Quarterly 26, xiii-xxiii.

[19] Yusuf, M., Adams, C., \& Dingley, K. (2014) Research Philosophy and Methodologies of e-Government: Update from ECEG and ICEG. In Proceedings of the 14th European Conference on e-Government: ECEG (p. 242). Academic Conferences Limited.

[20] World Bank (2014) Updated Income Classifications data available at data.worldbank.org (Access Date: $6^{\text {th }}$ May, 2015). 